Arch. Tierz., Dummerstorf 51 (2008) 3, 247-254

Institute of Animal Husbandry, Szent István University, Gödöllö, Hungary

FERENC PAJOR, ANDREA SZENTLÉLEKI, EDINA LÁCZÓ, JÁNOS TŐZSÉR and PÉTER PÓTI

\title{
The effect of temperament on weight gain of Hungarian Merino, German Merino and German Blackhead lambs
}

\begin{abstract}
Summary
We evaluated temperament of sheep using two temperament tests: temperament score test and flight test. Temperament score test: behaviour of animals was assessed in a 5-score system while weighing, spending $30 \mathrm{~s}$ on the scale. Flight time test: the time taken by an animal to move a set distance $(1.7 \mathrm{~m})$ after exiting a weighing scale into an open yard. 10 rams, 22 ewes Hungarian Merino, 13 rams, 19 ewes German Merino and 12 rams, 16 ewes German Blackhead lambs were lot-fed on 49 days, after weaning. The temperament score test was not related to the weight at weaning, therefore the measurement of the temperament was not affected by the weaning process $(\mathrm{P}>0.10)$. The gender not affected the temperament scores in either of observations or genotypes. In this investigation German Blackhead lambs were calmer, than Hungarian Merino lambs. The evaluation of the effects of temperament (temperament score test [TS] and flight time test [FT]) on body weight showed that lambs with calm temperament had higher weight at the end of fattening (TS: $44.88 \mathrm{~kg}$ and FT: $42.37 \mathrm{~kg}$ ) and higher average daily weight gain as well (TS: $492.18 \mathrm{~g} /$ day and FT: $430.03 \mathrm{~g} / \mathrm{day}$ ), compared to nervous animals (TS: $36.20 \mathrm{~kg}$ and $330.08 \mathrm{~g} /$ day, $\mathrm{P}<0.001$; FT: $36.73 \mathrm{~kg}$ and $345.77 \mathrm{~g} /$ day, $\mathrm{P}<0.05$ ). The lambs with good temperament had better fattening performance (higher weight at end of fattening, faster weight gain) than nervous lambs.
\end{abstract}

Keywords: temperament, temperament score test, flight time test, fattening, sheep, Hungarian Merino, German Merino, German Blackhead

\section{Zusammenfassung}

Titel der Arbeit: Der Einfluss des Temperaments auf die Mastleistung bei den Rassen Ungarische und Deutsche Merino sowie Deutsches Schwarzköpfiges Fleischschaf

Das Temperament der Schafe wurde nach dem Temperamentpunktetest (TS) und Fluchtzeittest (FT) bewertet. Beim TS wurde das Verhalten der Tiere bei einem 30 s dauernden Aufenthalt der Tiere auf der Waage nach einem 5-Punktesystem, beim FT die Zeit die ein Tier benötigt, um nach dem Verlassen der Waage eine Strecke von 1,7 Meter zurückzulegen, nach einem 3-Punktesystem bewertet. Verglichen wurden Tiere der Rassen Ungarische Merino ( $n=32)$, Deutsche Merino $(n=32)$ und Deutsches Schwarzköpfiges Fleischschaf $(n=16)$ beider Geschlechter. Beim TS wurden keine Zusammenhänge weder zum Gewicht beim Absetzen, welches je nach Rasse am 65. bis 71. Tag erfolgte, noch zum Geschlecht oder der Rasse der Tiere festgestellt. Die Deutschen Schwarzköpfigen Fleischschafe erwiesen sich als ruhiger als die Ungarischen Merino. Signifikante Einflüsse des TS und FT ergaben sich für das Körpergewicht am Ende der Mastperiode. So erreichte Lämmer mit ruhigem Temperament ein höheres Gewicht (TS: 44,88 kg; FT: 42,37 kg) und tägliche Zunahmen (TS: 492 g/Tag; FT: $430 \mathrm{~g} / \mathrm{Tag}$ ) als nervöse Tiere (TS: 36,20 kg bzw. $330 \mathrm{~g} / \mathrm{Tag}$; FT: 36,73 kg bzw. 346 g/Tag) Die ruhigeren Tiere erzielten bei allen Genotypen bessere Zuwachsergebnisse.

Schlüsselwörter: Temperament, Temperamentpunktetest, Fluchtzeittest, Mast, Schaf, Ungarische Merino, Deutsche Merino, Deutsches Schwarzköpfiges Fleischschaf

\section{Introduction}

Temperament is the inborn predominant feeling and encouragement of animals. It is broad term which implies a threat to which the body needs adjust. The steering of behaviour induces a broad range of neuroendocrine, psychological and physiological 
adaptability (BORELL, 2000). Connections between temperament and performances therefore are to be explained. Locomotory activity traits in connection with body weight also were described in model populations (HECKL-ENSSLIN et al., 1991). Temperament of productive livestock is defined as the animal's behavioural response to handling by humans (BURROW, 1997). Temperament of livestock species have been measured by subjective assessment of animal behaviour and using objective methods, such as the docility test and the flight speed (or flight time) test (BURROW, 1997). For example, HUTSON (1982) assessed the flight distance in merino sheep. HARGREAVES AND HUTSON (1990) studied the effect of gentling on heart rate, flight distance and aversion of sheep to handling.

STRITTMATTER (2001) described a lot of differences between sheep races in the activity of behaviour. Races are different in the social behaviour, too GRÄSERHERMANN and SAMBRAUS (2001). Several authors found relationship between temperament and live weight or other performances in cattle (BURROW et al., 1998; BURROW, 1997; BURROW and DILLON, 1997; NEINDRE et al., 1998).

Results of BURROW and DILLON (1997) presented, that the nervous cattle group had significantly lower average daily gain, than the calm group.

IVANOV et al. (2005) found that the ewes from the calm temperament type exhibited a higher lysozyme and complement concentrations in blood compared to the nervous type, suggesting a better innate immune defense against infections.

MURPHY et al. (1994) and NEINDRE et al. (1998) reported that mortality of lambs attributable to poor maternal behaviour was higher for the temperamental animals than for the calmer line (18 vs. $6 \%$ ). The fertility between calm and nervous ewes was significantly different $(\mathrm{P}<0.05)$ at the age of three years, and the calm ewes produced more milk $(\mathrm{P}<0.05)$ than nervous animals during the whole milking period (IVANOV and DJORBINEVA, 2003).

To sum up, the reports suggested that calm temperament is beneficial for the production and reproduction traits (live weight, growth, morbidity, fertility, milk production, and carcass quality), contrary to nervous animals.

The aim of this study was to investigate the temperament of Hungarian Merino, German Merino and German Blackhead lambs and to report the relationship between temperament and live weight, live and relative weight gain of lambs.

\section{Materials and methods}

10 rams, 22 ewes of Hungarian Merino (HM), 13 rams, 19 ewes of German Merino (GM) and 12 rams, 16 ewes of German Blackhead (GBH) lambs after weaning were lot-fed separately by gender on concentrate mix $(137 \mathrm{~g} / \mathrm{kg}$ dry matter [D.M.] of crude protein, $8.94 \mathrm{MJ} / \mathrm{kg}$ and $6.13 \mathrm{MJ} / \mathrm{kg}$ D.M. of netto energy $\left[\mathrm{NE}_{\mathrm{m}}\right.$ and $\left.\mathrm{NE}_{\mathrm{g}}\right]$ ) for 49 days. The stock kept in Törtel (Pest County, Hungary). The stock was controlled continuously by the Association of Hungarian Sheep Breeders. The examined lambs were taken part in the Fattening Performance Testing.

The age at weaning for Hungarian Merino lambs was 65 days, for German Merino lambs was 71 days, for German Blackhead lambs was 69 days. The live weight at weaning for Hungarian Merino lambs was $19.5 \mathrm{~kg}$ for rams and $19.4 \mathrm{~kg}$ in ewes, for German Merino lambs was $20.2 \mathrm{~kg}$ for rams and $20.5 \mathrm{~kg}$ for ewes, for German Blackhead lambs was $21.8 \mathrm{~kg}$ for rams and $21.2 \mathrm{~kg}$ for ewes, as well. The body weights 
were taken prior to and after the fattening period and daily weight gains and relative weight gains were also calculated.

The relative weight gain $(\%)$ :

$$
(\mathrm{LnBW} 2-\mathrm{LnBW} 1) / \mathrm{FP} \times 100
$$

where: Ln - natural logarithm, BW1 - body weight at the beginning of fattening $(\mathrm{kg})$, BW2 - body weight at the end of fattening ( $\mathrm{kg}$ ), FP - feedlot period (day).

Health condition and nutritional status of lambs were good during the experiment period.

Temperament was measured according to the temperament score test by TRILLAT et al. (2000). Behaviour of animals was assessed in a 5-score system at weighing, while spending $30 \mathrm{~s}$ on the scale:

1 calm, no movement

2 calm with occasional movements

3 calm with some more movements but without shaking the scale

4 abrupt episodic movements without shaking the scale

5 permanent episodic movements and shaking the scale.

Temperament of lambs was evaluated twice by temperament score test during the feedlot period, at the age of weaning and at the end of fattening. At the end of fattening the temperament was assessed by flight time test. Flight time (or flight speed) of individual animals was determined by method of BURROW (1988). This is the time taken by an animal to move a set distance $(1.7 \mathrm{~m})$ after exiting a weighing scale into an open yard. Distributions of mean flight time scores were normalised using $\ln$ transformation. Transformation of flight time scores did not affect the statistical significance of the results, so results from non-transformed data are presented herein, with levels of significance applying transformed data. Accordingly, three categories ( 1 - nervous, 2 - average, 3 - calm) based on normalized flight time were configured, where nervous was below $0.6 \mathrm{~s}$, average was 0.6 to $0.9 \mathrm{~s}$ and calm was above $0.9 \mathrm{~s}$. Each group approximately includes $33 \%$ of total animals.

Statistical analysis: data were statistically processed by SPSS 14.0 program package (ANOVA test, Kruskal-Wallis test, Pearson simple- and Spearman-correlation), furthermore, weight at the end of fattening, average daily weight gain and relative weight gain were analysed using the General Linear Model with the main effects of temperament score test ( 1 to 5 scores) and flight time test (3 categories). The following model was applied for statistical calculations:

$$
\mathrm{Y}_{\mathrm{ij}}=\mu+\mathrm{S}_{\mathrm{i}}+\mathrm{F}_{\mathrm{j}}+\mathrm{e}_{\mathrm{ij}}
$$

where: $Y_{i j}-$ measured fattening traits; $\mu$ - overall mean; $S_{i}$ - effects of temperament score (fixed effects: 5 classes); $F_{j}$ - effects of flight time test categories (fixed effects: 3 classes); $\mathrm{e}_{\mathrm{ij}}$ - residual error.

\section{Results and discussion}

Temperament was evaluated twice by temperament score test during the feedlot period, at weaning and at the end of fattening. At the end of fattening the temperament was measured by flight time test. Results of temperament score and flight time test by genotypes and gender are presented in Table 1. The temperament score at weaning was 3.35 for Hungarian Merino, 2.76 for German Merino and 2.48 for German Blackhead. The temperament score at end of the fattening was 3.34 for Hungarian Merino, 2.53 
for German Merino and 2.36 for German Blackhead. Results of temperament score test were not related to the weight at the weaning, therefore the measure of temperament was not affected by the weaning process $(\mathrm{P}>0.05)$.

The flight time at end of the fattening was $1.92 \mathrm{~s}$ for Hungarian Merino, $2.16 \mathrm{~s}$ for German Merino and 3.20 s for German Blackhead.

Table 1

Results of temperament score and flight time test according to gender and genotypes (mean \pm SD) (Temperamentpunktetest und Fluchtzeittest nach Geschlecht und Genotyp)

\begin{tabular}{|c|c|c|c|}
\hline & Hungarian Merino & German Merino & German Blackhead \\
\hline \multicolumn{4}{|c|}{ Temperament at weaning (score) } \\
\hline ram & $3.88 \pm 1.12$ & $2.85 \pm 1.28$ & $2.64 \pm 1.50$ \\
\hline ewe & $3.07 \pm 1.44$ & $2.67 \pm 1.16$ & $2.30 \pm 1.16$ \\
\hline total & $3.35 \pm 1.37^{\mathrm{a}}$ & $2.76 \pm 1.20$ & $2.48 \pm 1.33^{\mathrm{a}}$ \\
\hline \multicolumn{4}{|c|}{ Temperament at the end of fattening (score) } \\
\hline ram & $3.80 \pm 1.32$ & $2.62 \pm 1.12$ & $2.58 \pm 1.08$ \\
\hline ewe & $3.14 \pm 1.64$ & $2.47 \pm 0.96$ & $2.19 \pm 1.11$ \\
\hline total & $3.34 \pm 1.56^{\mathrm{aA}}$ & $2.53 \pm 1.02^{\mathrm{a}}$ & $2.36 \pm 1.10^{\mathrm{A}}$ \\
\hline \multicolumn{4}{|c|}{ Flight time at end of fattening $(s)$} \\
\hline ram & $1.95 \pm 0.64$ & $2.19 \pm 0.73$ & $3.38 \pm 2.14$ \\
\hline ewe & $1.91 \pm 0.51$ & $2.14 \pm 0.59$ & $3.03 \pm 1.68$ \\
\hline total & $1.92 \pm 0.54^{\mathrm{A}}$ & $2.16 \pm 0.64^{\mathrm{B}}$ & $3.20 \pm 1.88^{\mathrm{AB}}$ \\
\hline
\end{tabular}

$\mathrm{a}=$ significant difference between breeds $(\mathrm{P}<0.05)$; $\mathrm{A}, \mathrm{B}=$ significant differences between breeds $(\mathrm{P}<0.01)$

The results showed no differences in temperament (temperament score and flight time test) between the sexes in either of genotypes. In contrary to these results SAVAS et al., (2001) found great differences between males and females in behaviour abnormalities. Therefore the two data were contracted in this study.

Temperament scores were analysed applying Kruskal-Wallis test. There were not found differences between temperament scores at weaning and at the end of fattening. Relationships between two temperament scores were positive intermediate rank correlation (HM: $\mathrm{r}_{\text {rank }}=0.67 ; \mathrm{P}<0.01 ; \mathrm{GM}: \mathrm{r}_{\mathrm{rank}}=0.71 ; \mathrm{P}<0.01 ; \mathrm{GBH}: \mathrm{r}_{\mathrm{rank}}=0.55$; $\mathrm{P}<0.05)$. This observation corresponds with data published by TÖZSÉR et al (2004), which showed also intermediate correlation $\left(\mathrm{r}_{\text {rank }}=0.60, \mathrm{P}<0.01\right)$ in Hungarian Merino. The results showed differences between Hungarian Merino and German Blackhead at weaning $(\mathrm{P}<0.05)$ and at the end of fattening $(\mathrm{P}<0.001)$. In our sample, German Blackhead lambs were calmer, than Hungarian Merino lambs at weaning and at the end of fattening. STRITTMATTER (2001) also found lower locomotory activities in German Blackhead than in German Merino lambs.

Effects of temperament on live weight and weight gain according to genotypes are presented in figures 1,2 and 3 .

Figures show that calm animals had higher live weight, and better relative and absolute weight gain than average and nervous animals. Differences were significant among temperament categories in every genotype. All lamb temperament data were contracted. Effects of temperament (temperament score and flight time test) on live weight and weight gains are summarized in Table 2.

Temperament score was correlated with flight time $\left(\mathrm{r}_{\mathrm{rank}}=-0.61 ; \mathrm{P}<0.001\right)$. This observation corresponded with data published by BURROW and DILLON (1997).

The evaluation of the effects of temperament scores on body weight showed that lambs with calm temperament (1. category) had higher live weight at the end of 


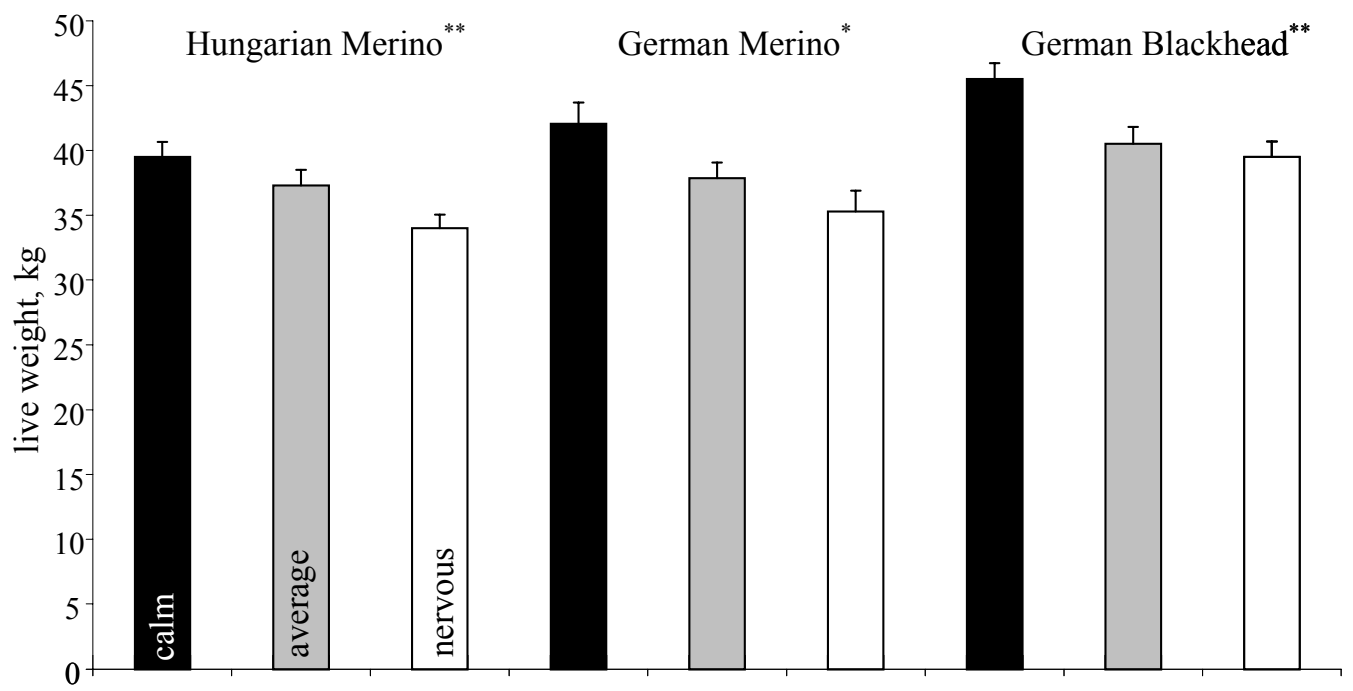

Fig. 1: Fattening traits of lambs according to genotypes and temperament categories (LSM \pm SEM)(live weight, $\mathrm{kg}$ ) (Mastleistungen der Lämmer nach Genotyp und Temperamentkategorien, [Lebendgewicht, kg])

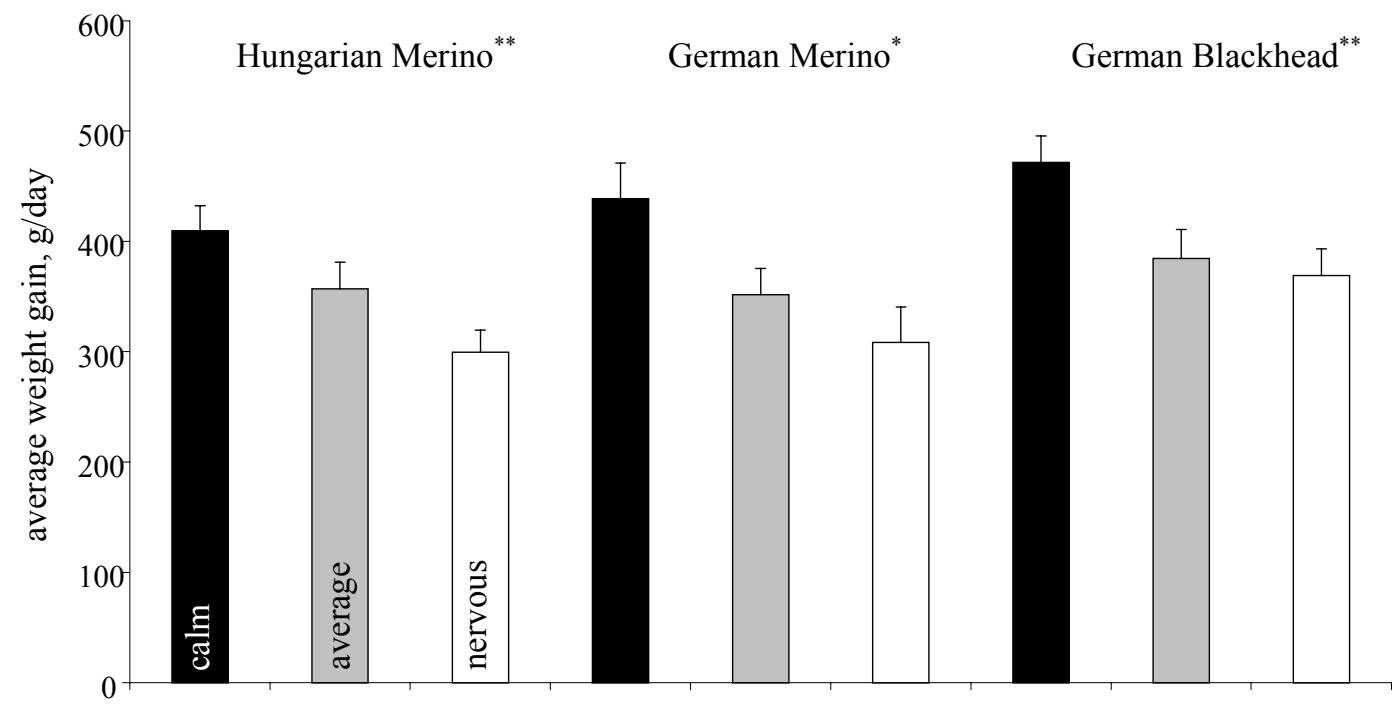

Fig. 2: Fattening traits of lambs according to genotypes and temperament categories ( $\mathrm{LSM} \pm \mathrm{SEM})($ average weight gain, g/day) (Mastleistungen der Lämmer nach Genotyp und Temperamentkategorien, [durchschnittliche tägliche Gewichterhöhung, $\mathrm{g} / \mathrm{Tag}]$ )

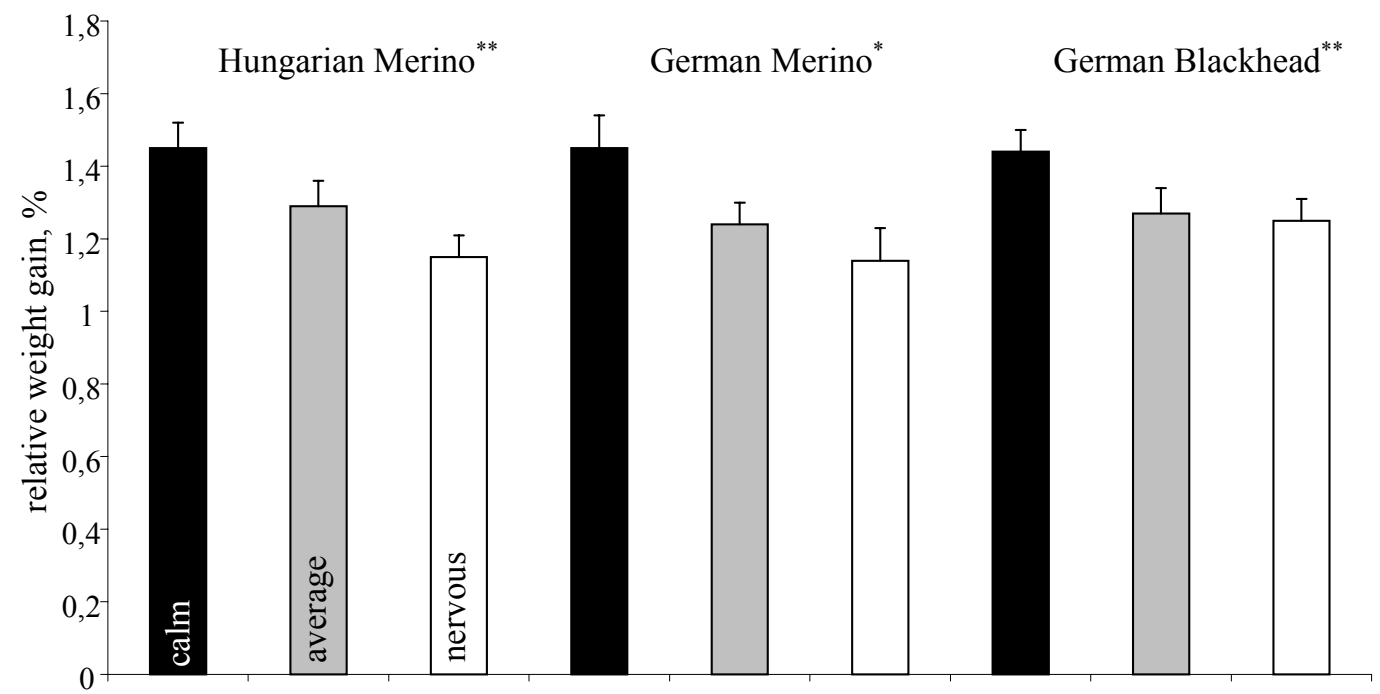

Fig. 3: Fattening traits of lambs according to genotypes and temperament categories (LSM \pm SEM) (relative weight gain, \%) (Mästung Eigenschaften von Lämmern nach Genotypen und Temperament-Kategorien [relative Gewichtserhöhung, \%])

* Significance levels among temperament categories $\mathrm{P}<0.05^{*} ; \mathrm{P}<0.01$ ** 
Table 2

LS means \pm standard error of fattening traits according to temperament tests (temperament score and flight time test) (Mittelwert und Standardfehler der Mastmerkmale nach Temperament- und Fluchtzeitpunktwerten)

\begin{tabular}{llcccc}
\hline & & $\mathrm{n}$ & Final weight, kg & Average daily weight gain, g/day & Relative weight gain, \% \\
\hline & 1 & 20 & $42.16 \pm 0.79^{\mathrm{ABC}}$ & $438.10 \pm 15.45^{\mathrm{ABC}}$ & $1.45 \pm 0.04^{\mathrm{ABC}}$ \\
Temperament & 2 & 18 & $39.99 \pm 0.89^{\mathrm{aD}}$ & $409.30 \pm 17.42^{\mathrm{DE}}$ & $1.41 \pm 0.05^{\mathrm{aDE}}$ \\
score test & 3 & 23 & $38.63 \pm 0.72^{\mathrm{A}}$ & $366.19 \pm 14.17^{\mathrm{A}}$ & $1.27 \pm 0.04^{\mathrm{aA}}$ \\
categories & 4 & 18 & $36.56 \pm 0.81^{\mathrm{BD}}$ & $336.08 \pm 15.84^{\mathrm{BD}}$ & $1.21 \pm 0.04^{\mathrm{BD}}$ \\
& 5 & 13 & $36.05 \pm 1.24^{\mathrm{aC}}$ & $319.10 \pm 24.34^{\mathrm{CE}}$ & $1.15 \pm 0.07^{\mathrm{CE}}$ \\
$\mathrm{P}$ & & & $<0.001$ & $<0.001$ & $<0.001$ \\
Flight & 1 & 31 & $36.28 \pm 0.68^{\mathrm{AB}}$ & $334.17 \pm 12.32^{\mathrm{AB}}$ & $1.22 \pm 0.03^{\mathrm{aA}}$ \\
time test & 2 & 32 & $40.05 \pm 0.69^{\mathrm{A}}$ & $390.52 \pm 11.34^{\mathrm{A}}$ & $1.34 \pm 0.03^{\mathrm{a}}$ \\
categories & 3 & 29 & $41.40 \pm 1.21^{\mathrm{B}}$ & $407.65 \pm 18.95^{\mathrm{B}}$ & $1.39 \pm 0.05^{\mathrm{A}}$ \\
$\mathrm{P}$ & & & $<0.001$ & $<0.01$ & $<0.01$ \\
\hline
\end{tabular}

$\mathrm{a}=$ significant difference between categories $(\mathrm{P}<0.05) ; \mathrm{A}, \mathrm{B}, \mathrm{C}, \mathrm{D}, \mathrm{E}=$ significant differences between categories $(\mathrm{P}<0.01)$

fattening $(42.16 \mathrm{~kg})$, average daily weight gain $(438.10 \mathrm{~g} /$ day $)$ and relative weight gain $(1.45 \%)$, compared to those having average (3. category: $38.63 \mathrm{~kg}, 366.19 \mathrm{~g} /$ day and $1.27 \%$ ), and poor (5. category: $36.05 \mathrm{~kg}, 319.10 \mathrm{~g} /$ day and $1.15 \%$ ) temperament. The relative weight gain is in connection with important fattening traits, e.g. ability of feed conversation and final weight.

The evaluation of the effects of flight time categories on body weight showed that nervous lambs (1. category) had lower weight at the end of fattening, lower average daily weight gain and relative weight gain, compared to those having average (2. category) and calm lambs (3. category). The lambs with good temperament had better fattening performance (higher weight at end of fattening, faster weight gain) than nervous lambs. The production vantage came up to the 5-6 kg live weight and 70$120 \mathrm{~g} /$ day weight gain.

The flight time and temperament score were correlated with weight at the end of fattening, average daily weight gain and relative weight gain by genotypes. The results are shown in Table 3.

\section{Table 3}

Phenotypic correlation (r) between temperament tests (temperament score and flight time test) and fattening traits according to different genotypes (Phänotypische Korrelationen [r] zwischen Temperamentpunktetest und Fluchtzeittest sowie Mastmerkmalen und Genotypen)

\begin{tabular}{llrrrrrrrr}
\hline Variable 1 & Variable 2 & \multicolumn{2}{c}{$\mathrm{HM}$} & \multicolumn{2}{c}{$\mathrm{GM}$} & \multicolumn{2}{c}{$\mathrm{GBH}$} & \multicolumn{2}{c}{ overall } \\
& & $\mathrm{r}$ & $\mathrm{P}$ & $\mathrm{r}$ & $\mathrm{P}$ & $\mathrm{r}$ & $\mathrm{P}$ & $\mathrm{r}$ & $\mathrm{P}$ \\
\hline \multirow{3}{*}{ Temperament } & flight time test & -0.63 & 0.001 & -0.64 & 0.001 & -0.57 & 0.01 & -0.61 & 0.001 \\
score test & live weight & -0.58 & 0.001 & -0.56 & 0.001 & -0.66 & 0.001 & -0.60 & 0.001 \\
& daily weight gain & -0.60 & 0.001 & -0.54 & 0.01 & -0.58 & 0.01 & -0.57 & 0.001 \\
& relative weight gain & -0.51 & 0.001 & -0.46 & 0.01 & -0.54 & 0.01 & -0.52 & 0.001 \\
\hline \multirow{2}{*}{ Flight time } & live weight & 0.42 & 0.05 & 0.41 & 0.05 & 0.56 & 0.01 & 0.53 & 0.001 \\
category & daily weight gain & 0.43 & 0.05 & 0.40 & 0.05 & 0.31 & $\mathrm{~N} . \mathrm{S}$. & 0.42 & 0.001 \\
& relative weight gain & 0.38 & 0.05 & 0.35 & 0.05 & 0.56 & 0.01 & 0.42 & 0.001 \\
\hline
\end{tabular}

$\mathrm{HM}=$ Hungarian Merino, $\mathrm{GM}=$ German Merino, $\mathrm{GBH}=$ German Blackhead

These results suggest that calm animals (those with low [1] score) may grow faster in a feedlot than nervous (temperamental) animals (those with high [5] score). It is highly probable that the higher growth rate of calm animals results from an increased feed intake, although the probability that the nervous animals using more energy in avoidance-type behaviour should not be ignored (BURROW and DILLON, 1997). 
It may be concluded that temperaments tests, like temperament score test and flight time test are inexpensive, quick and easy to implement on the farm. The gender was not affected the temperament scores in either of observations and genotypes. In this investigation German Blackhead lambs were calmer, than Hungarian Merino lambs at the weaning and at the end of fattening. Lambs with good temperament had higher average daily gain and weight at the end of fattening compared to those with poor temperament. Temperament scores showed a negative relationship to the average daily gain and weight at the end of fattening, this calm lambs grew better, than poor, nervous lambs.

With reference to direct and indirect advantages of evaluation of temperament we support development and using of temperament tests in Hungary, since implication of this trait has already been realised broad in the breeding work previously. As an evidence of it, temperament is being added as a new trait to the Australian beef genetic evaluation, Breedplan. Breedplan Estimated Breeding Values (EBVs) can be used for selection purposes by cattle breeders, to directly improve the temperament and to indirectly improve the carcass and meat quality in their progeny (BURROW, 2003). Also, the Sheep Genetics Australia is planning to offer Australian Sheep Breeding Values for temperament in the near future to Lambplan and Merinoselect customers (COLLINS and CONINGTON, 2005).

\section{Acknowledgement}

We appreciate and we would like to say thank for assistance of Sebők Mihály. This work was supported by Ministry of Education (OMFB 00790/2003) and Ministry of Agriculture (43063/2004).

BORELL VON, E.:

\section{References}

Stress and coping in farm animals. Arch. Tierz. 43 (2000), Sonderheft, 144-152

BURROW, H.M.; SEIFERT, G.W.; CORBET, N.J.:

A new technique for measuring temperament in cattle. Anim. Prod. Austr. 17 (1988), 154-157

BURROW, H.M; DILLON, R.D.:

Relationship between temperament and growth in a feedlot and commercial carcass traits of Bos indicus crossbreds. Aust. J. Exp. Agric. 37 (1997), 400-411

BURROW, H.M.:

Measurement of temperament and their relationship with performance traits of beef cattle. Anim. Breed. Abstr. 65 (1997), 478-495

BURROW, H.M.:

Improving cattle performance and meat quality by measuring temperament. On homepage of Cooperative Research Centre for cattle and Beef Quality. (2003), http://www.beef.crc.org.au

COLLINS, J., CONINGTON, J.:

Sheep Easy Breeding Group. Breeding easier-managed sheep. SAC, Scotland (2005), 38

GRÄSER-HERMANN, C.; SAMBRAUS, H.H.:

The social behaviour of East Friesian dairy sheep in larger groups. Arch. Tierz. 44 (2001), 421-433

HARGREAVES, A.L.; HUTSON, G.D.:

The effect of gentling on heart rate, flight distance and aversion of sheep to a handling procedure. Appl. Anim. Behav. Sci. 26 (1990), 243-252

HECKL-ENSSLIN, C.; GRAML, R.; HECKL, M.; BUTLER-WEMKEN VON, I.; PIRCHNER, F.; WEINGER, J.H.: Genetische Untersuchungen zur Bewegungsaktivität von Hausmäusen. Arch. Tierz. 34 (1991), 341-354.

HUTSON, G.D.:

'Flight distance' in merino sheep. Anim. Prod. 35 (1982), 231-235 
IVANOV, I.D.; DJORBINEVA, M.:

Assessment of welfare, functional parameters of the udder, milk productive and reproductive traits in dairy ewes of different temperament. Bulg. J. Agric. Sci. 9 (2003), 711-715

IVANOV, I.D.; DJORBINEVA, M.; SOTIROV, L.; TANCHEV, S.:

Influence of fearfulness on lysozyme and complement concentrations in dairy sheep. Revue Méd. Vét. 156 (2005), 8-9

MURPHY, P.M.; PURVIS, I.W.; LINDSAY, D.R.; NEINDRE, P.L.; ORGEUR, P.; POINDRON, P.:

Measures of temperament are highly repeatable in Merino sheep and some are related to maternal behaviour. Anim. Prod. Aust. 20 (1994), 247-250

NEINDRE, P.L.; MURPHY, P.M.; BOISSY, A.; PURVIS, I.W.; LINDSAY, D.; ORGEUR, P.; BOUIX, J.; BIBE, B.; NEINDRE, P.L.:

Genetics of maternal ability in cattle and sheep. Proc. 6th World Congr. Genet. Appl. Livest. Prod., Armidale, Australia 27 (1998), 23-30

SAVAS, T.; YURTMAN, Y.; KARAAGAC, F.; KÖYCÜ, E.:

Einfluss der intensiven Gruppenhaltung und Geschlecht auf Oral-Stereotypien und einige Verhaltensmerkmale bei Mastlämmern. Arch. Tierz. 44 (2001), 313-322

STRITTMATTER, K.:

Das verhalten von Schafen verschiedener Rassen bei der Weidenutzung von Rekultivierungsflächen des Bergbaues. Arch. Tierz. 44 (2001), Special Issue, 224-229

TÖZSÉR, J.; PÓTI, P.; PAJOR, F.; SZENTLÉLEKI, A.; MAROS, K.; ZÁNDOKI, R.; NIKODÉMUSZ, E.; BALÁZS, F.:

Evaluation of results on repeated scale test in cattle and sheep breeds. Állattenyésztés és Takarmányozás 53 (2004), 365-371 (in Hungarian)

TRILLAT, G.; BOISSY, A.; BOIVIN, X.; MONIN, G.; SAPA, J.; MORMENDE, P.; NEINDRE, P.L.:

Relations entre le bien-etre des bovines et les caracteristiques de la viande (Rapport definitif-Juin).

INRA, Theix, France (2000), 1-33

Received: 2007-04-13

Accepted: 2008-05-06

Authors:

FERENC PAJOR*

ANDREA SZENTLÉLEKI

EDINA LÁCZÓ

Prof. Dr. habil. JÁNOS TŐZSÉR

Ass. Prof. habil. PÉTER PÓTI

Szent István University

Faculty of Agricultural and Environmental Sciences

Institute of Animal Husbandry

2100-H Gödöllö

Páter K. 1

Hungary

*Corresponding author

email: pajor.ferenc@mkk.szie.hu 